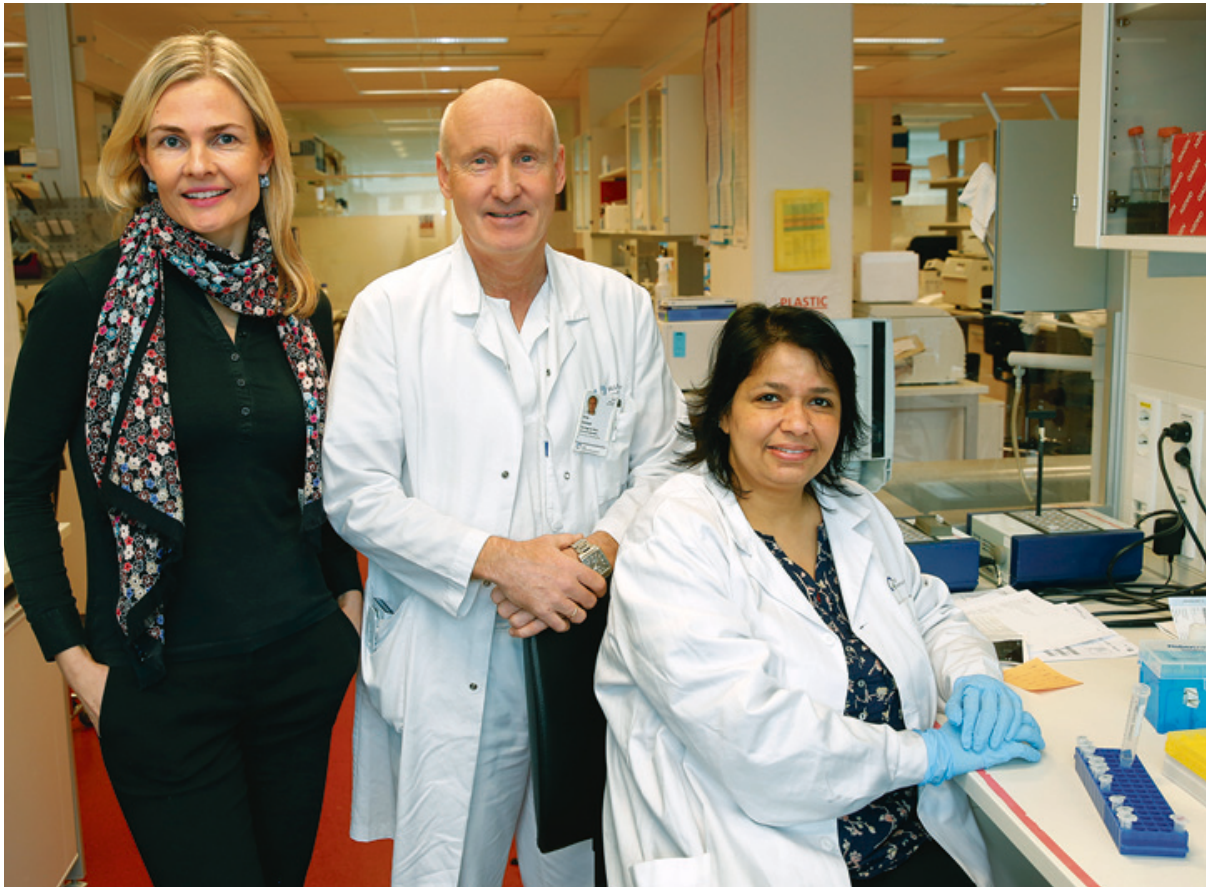

Tre av forskerne bak studien. Fra venstre Johanna Olweus, Arne Kolstad og Shraddha Kumari. Foto: Terje Heiestad/Millimeterpress

\section{Immunstimulering mot follikulært lymfom?}

Det finnes i dag ingen helbredende behandling av follikulært non-Hodgkins lymfom. En ny norsk studie viser at det er mulig å stimulere immunforsvaret til å bekjempe sykdommen.

Follikulært lymfom diagnostiseres vanligvis sent. Etter behandling vil de fleste pasientene få residiv og til slutt dø av sykdommen. Norske forskere har nå funnet en ny behandlingsmetode. Resultatene ble publisert i tidsskriftet Blood i januar 2015. (1). Metoden går ut på å aktivere pasientens immunceller slik at de oppfatter kreften som fremmed og dermed går til angrep på kreftcellene. Dette gjøres ved å skape inflammasjon i en lymfeknute ved bruk av stråleterapi og injeksjoner med anti-CD20antistoff og dendrittiske celler som er dyrket frem fra hvite blodceller fra pasientens blod.

Studien omfattet 14 pasienter med follikulært lymfom som ble behandlet tre ganger mot ulike lymfeknuter. Fem av de 14 ble bedre, deriblant to som fikk komplett remisjon. Alle pasientene som hadde behandlingseffekt, hadde sterke immunresponser mot egne lymfomceller, og tumorreduksjonen var korrelert med størrelsen på immunresponsen.

- Denne studien viser at det er mulig å oppnå sterke immunresponser mot kreftcellene og gode behandlingseffekter ved lokal immunstimulerende behandling hos pasienter med utbredt lymfom, sier overlege Arne Kolstad, som leder studien.

- Dette kan tyde på at det er mulig å utsette eller forhindre at pasientene trenger cytostatikabehandling. Større studier er nødvendig for å bekrefte resultatene, og det er planlagt en ny studie i 2015, sier Kolstad.

\section{Satsingsområde og Jebsen-senter}

Arne Kolstad er leder for det nyoppstartede satsingsområdet for immunterapi mot kreft ved Oslo universitetssykehus og partner i K.G. Jebsen-senter for immunterapi mot kreft ved Universitetet i Oslo. Senteret er ledet av professor Johanna Olweus. Dette prosjektet er et samarbeid mellom Kolstads og Olweus' forskningsgrupper. Kolstad er overlege ved Avdeling for kreftbehandling ved Oslo universitetssykehus, Radiumhospitalet, og har tillegg en $50 \%$ forskerstilling med støtte fra Kreftforeningen. Ideen til prosjektet fikk han under et opphold som gjesteprofessor ved Stanford University i USA i 2007.

\section{Lise Mørkved Helsingen}

Tidsskriftet

\section{Litteratur}

1. Kolstad A, Kumari S, Walczak M et al. Sequential intranodal immunotherapy induces antitumor immunity and correlated regression of disseminated follicular lymphoma. Blood 2015; 125: 82-9.
Ordforklaringer

Follikulært non-Hodgkins lymfom: Dette er den vanligste formen for indolent non-Hodgkins lymfom. Pasientene har ofte utbredt sykdom ved symptomdebut og ikke sjelden beinmargs infiltrasjon. Sykdommen er følsom for stråleterapi, kjemoterapi og immunterapi, men det finnes ingen kur.

T-celler: Dette er hvite blodceller som gjennom sin T-cellereseptor kan gjenkjenne peptider presentert på vevstypemolekyler på overflaten av infiserte celler. De kan også gjenkjenne peptider fra kreftceller og anses å spille en viktig rolle i kroppens forsvar mot kreft.

Dendrittiske celler: Dette er hvite blodceller som har evnen til å ta opp materiale fra f.eks. bakterier og virus og deretter presentere peptider fra disse på vevstypemolekyler på celleoverflaten. Dette kan stimulere T-celler til angrep mot infeksjonen. Dendrittiske celler kan også presentere peptider fra kreftceller og dermed hjelpe T-cellene til å angripe kreftcellene.

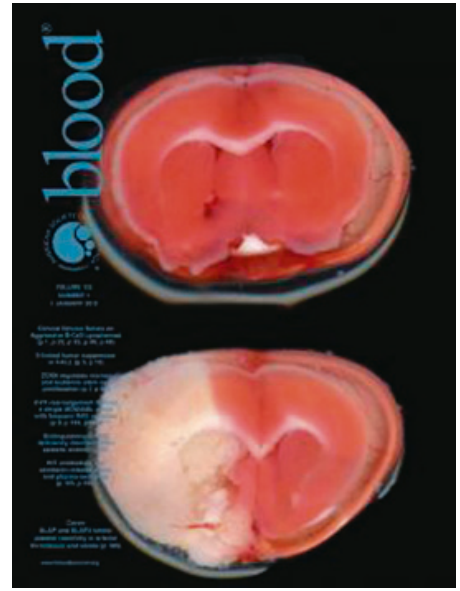

Studien ble publisert i det prestisjetunge tidsskriftet Blood i januar 2015 